\title{
Application of Leaf Fertilizer Using Nano Technology To Read Vegetative Growth of Vanda sp.
}

\author{
Dwi Zulfita $^{*}$, Maulidi ${ }^{1}$ and Agus Hariyanti ${ }^{1}$ \\ ${ }^{1}$ Agrotechnology Study Program, Faculty of Agriculture, Tanjungpura University \\ Jl. Prof. Dr. H. Hadari Nawawi Pontianak 78124, Indonesia \\ *Corresponding author : dwi.zulfita@faperta.untan.ac.id
}

\section{ARTICLE HISTORY}

Received : 17 February 2019

Revised : 12 March 2019

Accepted : 20 April 2019

\section{KEYWORDS:}

Vanda sp. Orchid

Leaffertilizer

Growth

Nano Technology

\begin{abstract}
This study aims to find the best fertilizer concentration of Growmore leaves to stimulate vegetative growth of Orchid Vanda sp. The study was conducted at the Tanjungpura University Faculty of Agriculture's experimental garden screen house and took place from March 52018 to July 12, 2018. The research design used was a Completely Randomized Design with one treatment factor namely Growmore Leaf Fertilizer concentration (D) with 5 levels of treatment namely Concentration $1 \mathrm{~g}$ /liter of water (d1), 2 g/liter of water (d2), $3 \mathrm{~g} /$ liter of water (d3), $4 \mathrm{~g} /$ liter of water (d4) and $5 \mathrm{~g} /$ liter of water (d5). Each treatment was repeated 5 times. The variables observed were the increase of number of leaves (strands), the increase of leaf length $(\mathrm{cm})$, the increase of number of roots (strands) and the increase of root length $(\mathrm{cm})$. The results shows that the application of Growmore fertilizer in the amount of a concentration of $1 \mathrm{~g} /$ liter of water, $2 \mathrm{~g}$ /liter of water, $3 \mathrm{~g} /$ liter of water and $4 \mathrm{~g}$ /liter of water show an increase in the number and length of leaves of Vanda sp. which is just as good. The Growmore fertilizer concentration is the best for the number of roots and the length of the roots of Vanda sp. Orchid seeds in the amount of $3 \mathrm{~g} /$ liter of water.
\end{abstract}

This is an open access article under the CC-BY-SA license.

\section{INTRODUCTION}

Orchid plants belong to members of the family Orchidaceae, which is one of the families that has approximately 43,000 species from 750 different generations (Suradinata et al., 2012). In Indonesia, orchids have a quite large potential, seen from a great amount of germplasm sources and their uniqueness.

The high demand for Vanda orchids is not supported with adequate seed production. The limitation is handled with a mass propagation, such as plant propagation in vitro in the laboratory, both through seed culture and organ culture. Orchid seeds that are removed from the bottle (acclimatization) require sufficient nutrients for their growth and development. One of the ways to help meet the nutrient needs of orchid seeds is to use fertilizer.

Vegetative growth of orchid plants is very susceptible to environmental conditions that are different from its initial environment, namely using bottles with tissue culture media. At this stage, seeds need sufficient nutrients so it could be produced in good quality. However, in this condition, seedlings could be withered due to various things, including the failure to fulfill their needs for nutrients. After 1 - 3 months the seeds are considered able to adapt to the environment, if the seeds show good growth and development towards the treatment given.

Therefore, at this vegetative growth stage, fertilizer needs to be given to spur the growth and development of orchid seedlings. Concentration of fertilization, is also a matter that needs attention, so the nutrients that will be used for the process of growth and development of seeds are fulfilled. If the seeds are fertilized with a high concentration, it will give a negative effect on growth, and vice versa.

Nano technology makes it possible for acclimatization applications because the raw material for making nanoparticles can be sourced from natural resources. Nano particles are a part of nanotechnology, which has developed rapidly since 2000 (Suwarda, 2010). Nano technology is useful in many ways, including; improve the efficiency of the use of fertilizers and natural materials in the soil, study the mechanism and dynamics of nutrients in the soil. Therefore with the application of nanotechnology, it is expected that a smaller chemical molecules would appear so they will be easily absorbed in plant tissues (Priangga et al., 2013). 
Vanda Orchid is an epiphytic plant, and it makes the absorption of nutrients from roots is very limited. According to Iswanto (2001) the absorption of nutrients in the Vanda orchid plant occurs 90\% through leaves. Vanda orchid plants have a very slow growth rate which is influenced by its maintenance, including the concentration of fertilizer given to the plants. Efforts to increase the growth of Vanda orchids can be done by giving fertilizer through leaves, because leaf fertilizers have nutrients needed by the orchid plants. One of the fertilizers used is Growmore leaf fertilizer that use nanotechnology as an optimization of nutrient absorption in plant tissues.

According to Shofwaturahman (2013), Growmore is a complete leaf fertilizer in the form of blue crystals, which very easy to dissolve in water, can be absorbed easily by plants by spraying it on the leaves. The nutrient composition contained by Growmore 20-20-20 fertilizer is N 20\%, P2O5 20\% and K20 20\%. Another element is Ca 0.05\%; Mg 0.10\%; S 0.20\%; B 0.02\%; 0.05\% Cu; Fe 0.10\%; Mo0.05\% and $\mathrm{Zn} 0.05 \%$. The recommended concentration is $1-3 \mathrm{~g} /$ liter of water. This study aims to obtain the best Gromore liquid fertilizer concentration for vegetative growth of Vanda sp. Orchids.

\section{MATERIALS AND METHODS}

This research was conducted at the screen house of Faculty of Agriculture, Tanjungpura University, Pontianak and took place from March 5, 2018 - July 12, 2018.

\subsection{Research Design}

This study was carried out in a completely randomized design (CRD) with 1 treatment factor and 5 replications. The factors tested were Growmore fertilizer concentration consisting of 5 levels, which are $\mathrm{d} 1$ (concentration of $1 \mathrm{~g} /$ liter of water), $d 2$ (concentration of $2 \mathrm{~g} /$ /iter of water), $\mathrm{d} 3$ (concentration of $3 \mathrm{~g} /$ liter of water), $\mathrm{d} 4$ (concentration of $4 \mathrm{~g} /$ liter of water) and d5 (concentration of $5 \mathrm{~g} /$ liter of water).

\subsection{Implementation of Research}

The materials used were 1 year old Vanda orchid plantlets, plastic pots, fern roots, MOSS, pesticides and Sray 2 nano tools and Growmore leaf fertilizers. The planting medium consists of Styrofoam which is cut into small pieces with the measurement of $5 \times 5 \mathrm{~cm}$, and the sterilized ferns roots. The media was being put into a pot with a diameter of $10 \mathrm{~cm}$, with Styrofoam at the bottom of the pot, while the upper part is a piece of root fern. Seeds are removed from the bottle using wire, washed, and air dried. Seeds that have been prepared are then planted in the pot with moss media. Then, covered with white plastic and tied using rubber bands. Holes are made through the plastics so that the seeds can quickly adapt to their new environment. Seeds that are 2 weeks old are transferred to individual pots ( 1 pot is planted with 1 seed). Seeds are placed in the shade of black paranet, and arranged in accordance with the Complete Random Design. Watering the seeds is done using handsprayer, in the morning and evening. Treatment begins at seedlings that are 1 week old after being removed, and given with an interval of 3 days according to the concentration of treatment. The study was conducted for 3 months.

\subsection{Observation Variable}

The variables observed in this study were: (1). Number of leaves (strands). The number of leaves is calculated at the end of the study. The calculated leaves are leaves that have been opened perfectly. (2). Increase in Leaf Length $(\mathrm{cm})$. The length of the leaf is measured from the base of the leaf to the tip of it. (3). Increase in the number of roots (strands) and (4). Increase in Root Length (cm). All variables observed were measured at the beginning and at the end of the study. Each variable data is calculated at the end of the study, and reduced by data at the beginning of the study.

\subsection{Data Analysis}

Data from observations were analyzed statistically using analysis of variance ( $F$ test). If the $F$ test shows a significant effect for each treatment, then we proceed with Duncan's multiple distance test at the level of 5\%.

\section{RESULTS AND DISCUSSIONS}

\subsection{Results}

The results of variance on the variables observed showed that the administration of Growmore fertilizer at various concentrations affected the increase in number of roots, increase in number of leaves and increase in leaf length and increase in root length. The average data of all variables observed in various Growmore fertilizer concentrations are presented in Table 1 and the performance of Vanda sp. Orchid seeds. in various Growmore fertilizer concentrations can be seen in Figures $1,2,3$.

Table 1. Increasing number of roots, increasing number of leaves, increasing leaf length and increasing root length at various Growmore fertilizer concentrations

\begin{tabular}{|c|c|c|c|c|}
\hline $\begin{array}{c}\text { Gromore fertilizer } \\
\text { concentration (g/liter of water) }\end{array}$ & $\begin{array}{l}\text { Increase in the number of } \\
\text { roots (strands) }\end{array}$ & $\begin{array}{l}\text { Number of Leaves } \\
\text { (strands) }\end{array}$ & $\begin{array}{l}\text { Increase in Leaf Length } \\
\qquad(\mathrm{cm})\end{array}$ & $\begin{array}{l}\text { Added root length } \\
(\mathrm{cm})\end{array}$ \\
\hline 1 & $0,95 \mathrm{~b}$ & $2,90 \mathrm{ab}$ & $0,71 \mathrm{a}$ & $0,77 \mathrm{~b}$ \\
\hline 2 & $1,19 \mathrm{~b}$ & $2,70 \mathrm{ab}$ & $0,71 \mathrm{a}$ & $0,66 \mathrm{~b}$ \\
\hline 3 & $1,85 \mathrm{a}$ & $3,05 \mathrm{a}$ & $0,82 \mathrm{a}$ & $1,54 \mathrm{a}$ \\
\hline 4 & $0,95 \mathrm{~b}$ & $2,50 \mathrm{ab}$ & $0,64 \mathrm{ab}$ & $0,41 \mathrm{~b}$ \\
\hline 5 & $0,90 \mathrm{~b}$ & $2,40 \mathrm{~b}$ & $0,47 \mathrm{~b}$ & $0,63 \mathrm{~b}$ \\
\hline KK (\%) & 22,58 & 14,88 & 21,91 & 17,08 \\
\hline
\end{tabular}

Note : Numbers in the column followed by the same letter mean not different according to Duncan's multiple distance test 5\% 

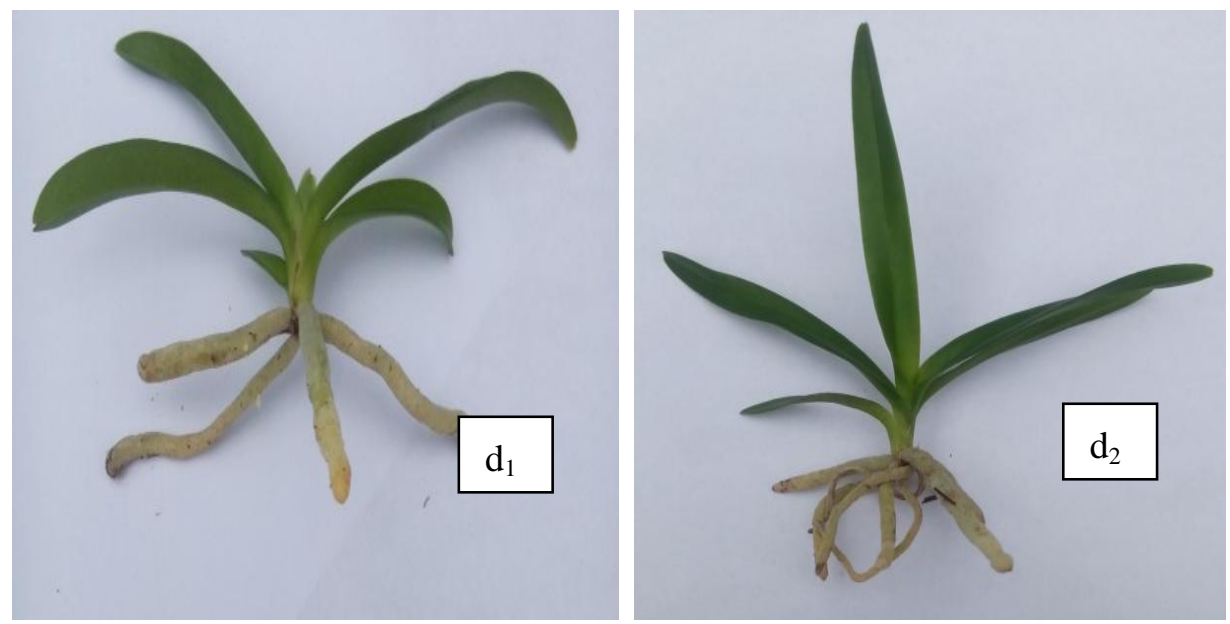

Figure 1. Performance of Vanda sp. Orchid seeds. in treatment $\mathrm{d} 1$ (concentration of $1 \mathrm{~g} / \mathrm{liter}$ of water) and d2 (concentration of 2 g/liter of water).
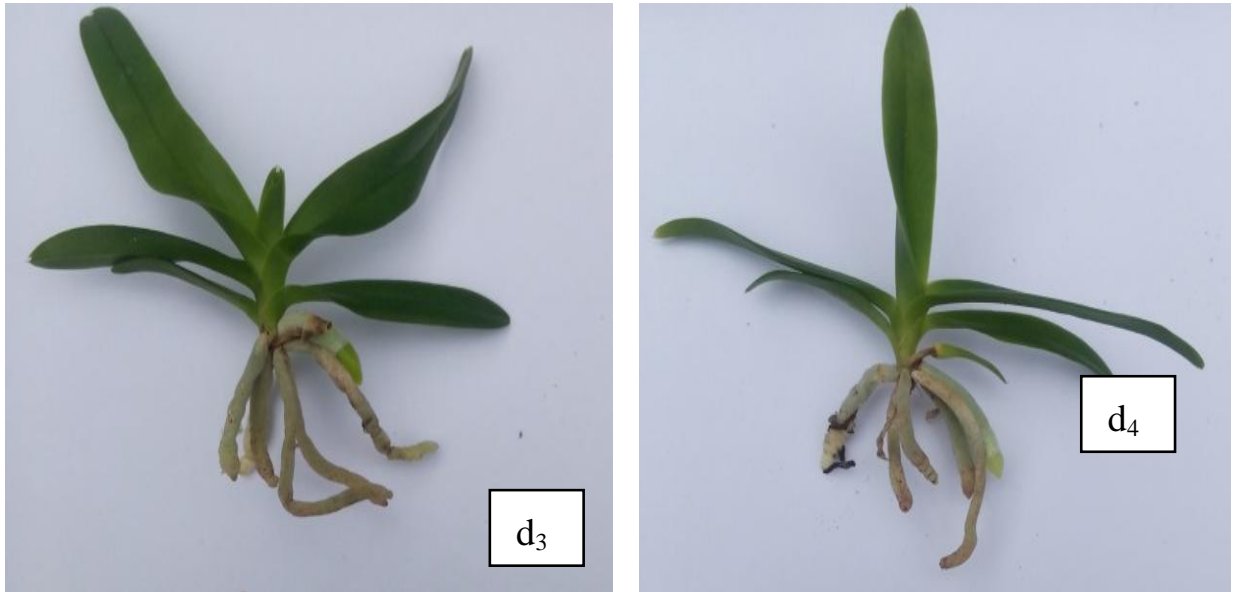

Figure 2. Performance of Vanda sp. Orchid seeds. in treatment $d 3$ (concentration of $3 \mathrm{~g} /$ liter of water) and d4 (concentration of 4 g/liter of water).

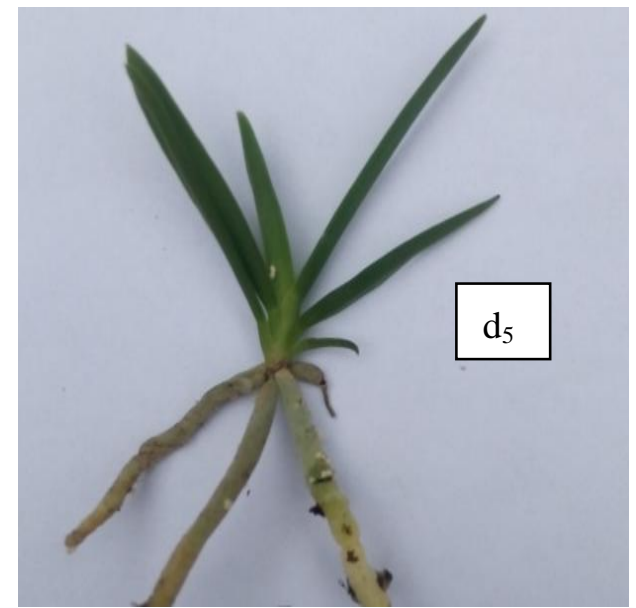

Figure 3. Performance of Vanda sp. Orchid seeds. at treatment d5 (concentration of $5 \mathrm{~g} /$ liter of water)

\subsection{Discussion}

The results shows that Growmore fertilizer given with a concentration of $3 \mathrm{~g} /$ liter of water was having a significantly different result especially in the increase of number of roots and increase in root length. The increase in leaf length and number of leaves in the application of Growmore fertilizer with a concentration of $3 \mathrm{~g} /$ liter of water was significantly different compared to gromore fertilizer with a concentration of $5 \mathrm{~g} /$ liter of water but 
not different when compared with the fertilizer Growmore concentration of $1 \mathrm{~g} /$ liter of water, $2 \mathrm{~g} /$ liter water and $4 \mathrm{~g} /$ liter of water. Fertilizer Growmore concentration of $1 \mathrm{~g}$ / liter of water, $2 \mathrm{~g}$ / liter of water and $3 \mathrm{~g} /$ liter of water was significantly different from the length increase of Vanda Orchid roots with fertilizer Growmore concentration of $5 \mathrm{~g} /$ liter of water.

This shows that the application of fertilizer with a concentration of $1 \mathrm{~g} /$ liter of water, $2 \mathrm{~g} /$ liter of water and $3 \mathrm{~g} /$ liter of water can stimulate the increase in the number of roots, root length, leaf number and leaf length. It means that nutrients contained in in fertilizers can be used by seeds for the growth process. The application of Growmore fertilizer with a concentration of $3 \mathrm{~g} / \mathrm{liter}$ of water is the best concentration even though on the other hand the administration of Growmore fertilizer with a concentration of $1 \mathrm{~g} /$ liter of water is an effective concentration. Meanwhile, Growmore fertilizer with a concentration of $5 \mathrm{~g} /$ /ite water shows the vegetative growth of orchid seeds slower. This is because the Growmore fertilizer used exceeds the recommended concentration so that it will inhibit plant metabolism, causing plant growth to be inhibited

Growmore is a complete fertilizer containing $20 \% \mathrm{~N}$ nutrients, 20\% P205 and 20\% K20. Another element is Ca 0.05\%; Mg 0.10\%; S 0.20\%; B 0.02\%; 0.05\% Cu; Fe 0.10\%; Mo $0.05 \%$ and $\mathrm{Zn} 0.05 \%$. (Anonim, 2012). Growmore fertilizers contain NPK elements, where potassium is a nutrient that acts as an activator of various enzymes that are essential in photosynthetic reactions. According to Mengel and Kirkby (1987) and Husma (2010) potassium can increase plant photosynthesis through an increasing photophosphorylation will produce ATP and NADPH. In addition to NPK elements, there are also nutrients found in Growmore, namely Mg. According to Laegreid et. al (1999) $\mathrm{Mg}$ element is a constituent of chlorophyll pigment in plants which plays a role in taking and converting light energy into $\mathrm{Mg}^{2+}$ form which can be used in photosynthesis. The elements contained in Growmore are basic ingredients to form cell organelles contained in plant cells, which will form a network and will develop into plant organs, one of which is leaves.

In this study the increase in the number of leaves and the length of leaves given Growmore was the concentration of $1 \mathrm{~g} /$ liter of water, $2 \mathrm{~g} /$ liter of water, 3 $\mathrm{g} /$ liter of water and $4 \mathrm{~g} /$ liter of water as well as compared to the fertilizer Growmore concentration of $5 \mathrm{~g}$ /liter of water. The large number of leaves and longer leaves will increase the amount of chlorophyll so that the orchid seeds at the same photosynthetic rate can produce more photosynthates to be used in the growth process.

Photosynthate produced in photosynthesis will be used to increase the number of roots and root length. Table 1 shows that the increase in the number of roots and the increase in root length given Growmore concentration of $3 \mathrm{~g} /$ liter of water is better compared to the administration of fertilizer Growmore concentration of $1 \mathrm{~g}$ / liter of water, $2 \mathrm{~g}$ / liter of water, $4 \mathrm{~g}$ /liter of water and $5 \mathrm{~g} /$ liters of water. According to Hendaryono (1998) that Growmore fertilizer stimulates formation and increases root length.

The micro nutrients contained in Growmore greatly help the process of growing Vanda orchid seeds. According to Surtinah (2010) Boron plays a role in strengthening cell walls. Ferum is needed in the formation of cytochromes that play a role in photosynthesis, Cuprum is contained in chloroplasts as a constituent of plastocyanin and chlorophyll stabilator, Zincum as a catalyst for the formation of tryptopan, an amino acid which is the initial compound in formation Auxin, Molybdenum as an activator and constituent of citrate reductase enzyme, is an enzyme that works to help change NO3-ions into NH3 which is ready to be used for the formation of amino acids and proteins and is used for cell division and enlargement.

\section{CONCLUSION}

The application of Growmore fertilizer with a concentration of $1 \mathrm{~g} /$ liter of water, $2 \mathrm{~g}$ / liter of water, 3 $\mathrm{g} /$ liter of water and $4 \mathrm{~g} /$ liter of water shows the increase in the number and length of leaves of Vanda sp. Orchid seeds. which is just as good. The Growmore fertilizer concentration is the best for the number of roots and the length of the roots of Vanda sp. Orchid seeds is $3 \mathrm{~g} /$ liter of water.

\section{REFERENCES}

Anonymous, 2012. Brosur Growmore. http://www.growquick.net/hom e.html. 2 April 2016.

Hendaryono, S. 1998. Budidaya Anggrek dengan Bibit dalam Botol. Kanisius. Yogyakarta.

Husma, M. 2010. The effect of organic materials and $\mathrm{K}$ fertilizer to the growth and yield of melons (Cucumis melo L.) (Written in Indonesian language) Thesis. Unhalu. Kendari. Diakses pada tanggal 28 Mei 2017.

Iswanto, H. 2001. Anggrek Dendrobium. Agromedia Pustaka. Jakarta

Laegreid, M., O. C. Backman dan O. Kaarstad. 1999. Agriculture Fertilizers and The Enviroment. CABI Publishing. Norway.

Mengel, K. and E.A. Kirkby. 1987. Principles of plant nutrition. 4th edition. Internatoinal Potash Institute, Bern/Switzerland

Priangga, Riky., Suwarno., Hidayat, Nur., 2013. The Effect of level of liquid organic fertilizer and their effects to production of dry yield equilibration of leaves and stems of elephant grass at $4^{\text {th }}$ defoliation (Written in Indonesian language). Jurnal Ilmiah Peternakan. 1(1): 76-82

Shofwaturahman, I. 2013. Cara Pemupukan Tanaman Hias Anggrek Dendrobium.

http://HortiFresh-caramemupuk-tanaman-hiasanggrek-Dendrobiu m.htm. Diakses pada tanggal 4 Juli 2017.

Suradinata, Y.R., Nurani, A., Setiadi, A., 2012. Effect of combination of planting media and green manure to the growth of orchid Dendrobium sp. at acclimatization stage (Written in Indonesian language). J. Agrivigor. 11(2): 104-11.

Surtinah, 2010. Agronomi Tanaman Budidaya. Alaf Pekanbaru.

Suwarda, Rosniyati., Maarif, M.S., 2010. The development of technology innovation of nanoparticles with PAT basis to create competitive products (Written in Indonesian language). Jurnal Teknik Industri, 104-122. ISSN: 1411-6340. 